\title{
USING WORD LIST ON THE WORD WALL STRATEGY ON STUDENTS' VOCABULARY LEARNING RESULT
}

\author{
Azizah $^{1}$, Sri Marina Ulfah ${ }^{2}$
}

Universitas Islam As-syafiiyah Jakarta

\begin{abstract}
This research principally aims to investigate whether or not word list on the word wall significantly affects students' vocabulary learning result. The research samples were taken using cluster random sampling, with the total number of samples being 70 students. The location of this research was SMPN 198 Jakarta. The research methodology adopted was quasi-experiment method with the research design being posttest only control group design. To collect the data, the students were given objective test, numbering 50 items. The research data were analyzed by using ONE-WAY ANOVA. The findings indicated that there was significant difference of post-test score between the students who received Word List Word Wall Strategy and students who did not receive Word List on the Word Wall. The writer found the significant level (Sig) in line with the ANOVA statistic was 0.000 which was lower than 0.05 means that Ho is rejected and $\mathrm{Ha}$ is accepted.it means that Word List on the Word Wall Strategy has significant effect on students' vocabulary learning result.
\end{abstract}

The Key words: Word list strategy, Word Wall, Vocabulary Learning Result

\section{Introduction}

Vocabulary is one of the skills that students need for success in their studies and some teacher believe, the students have different vocabulary skills and they use different strategies when they try to recall new words. Anderson and krathwohl's Taxonomy (2001) classified the result of learning in three area that 
must be considered in each learning, process and the three domains are: 1) Remembering: used to produce or retrieve definitions, facts, lists, or to recite previously learned information. 2) Understanding: constructing meaning from different types of functions be they written or graphic messages, or activities like interpreting, classifying and explaining. 3) Applying: carrying out or using a produce through executing or implementing.

Depdiknas (1999) stated "the goal of vocabulary learning of junior high school student who use English as a foreign language is to prepare themselves with vocabulary that can be used in expressing idea and communicating with other people, they are also expected to master 1,000 words.

However, the result of national examination in 2016 is lower than the result of national examination in 2015 with the average percentage in 2015 is $62.18 \%$ while in 2016 is $58.57 \%$, so the score deceased into $3.61 \%$. it can be concluded that the students have the problem in acquiring English vocabulary.

For this reason, this research is conducted to investigate whether or not appropriate strategy can overcome students' difficulties in acquiring the English vocabulary. One of the strategies is word list on the word wall strategy that help the students acquire the vocabulary. Thornbury (2002) stated that by using wordlist is one of the Strategies to acquire the vocabulary easily and wordlist can be applied in the classroom because it is cheap and widely used among the students, it also can be learned in a short time.

Some previous relevant researches revealed that word list on the word wall Strategy can improve students' vocabulary learning result is GulsinCosgun (2016) 
using a word list on the word wall in the class is an effective vocabulary learning strategy to improve their repertoire of words. The findings attract the interest of both foreign language teachers and students, and encourage them in the way of adopting and mentioned strategy in their studies.

Based on the explanation above, this research aims to find out the effect of using Word List on the Word Wall Strategy on grade eight students' vocabulary learning result at SMPN 198 Jakarta. To examine the effect of using Word List on the Word Wall Strategy on grade eight students' vocabulary learning result at SMPN 198 Jakarta the research question is formulated as follows: " is there any effect of using Word List on the Word Wall Strategy on grade eight students' vocabulary learning result at SMPN 198 Jakarta?

\section{Methodology}

\section{Hypotheses}

To find out whether or not there is significant effect of using Word List on the word wall strategy on grade eight students' vocabulary learning result, the hypotheses are formulated as follows:

\section{Null Hypothesis (Ho)}

There is no significant effect of using word list on the word wall strategy on grade eight students' vocabulary learning result at SMPN 198 Jakarta.

\section{Alternative Hypothesis (Ha)}

There is significant effect of using word list on the word wall strategy on grade eight students' vocabulary learning result at SMPN 198 Jakarta.

\section{Research Design}


In this research, the researcher used a quasi experimental method, in which the treatment condition did not allow a strict control. The design of this research was posttest only control group design. The first group namely as experimental that received word list on the word wall strategy and other group namely as control group that did not receive word list on the word wall strategy. Both groups were given posttest.

\section{Population \& sample}

The population of this research is grade eight students at SMPN 198 Jakarta in academic year 2016/2017 at the first semester, consisting of 350 (three hundred and fifty) students.To determine the sample of this research, the writer used Cluster Random Sampling. The number of students that participated in this research is about 70 (Seventy) students divided into two classes consisting each of 35 students in VIII E as experiment class and 35 students in VIII G as control class.

\section{Variables and Measures}

In this research, independent variable is Word List on the Word Wall Strategy and dependent variable in this research is vocabulary learning result. To measure students' vocabulary learning result, the writer took score from indicators of vocabulary learning result, as follows:

1. The Students are able to recognize the synonym of words given

2. The students are able to find the antonym of the new words given

3. The students are able to choose adjective correctly In the sentence

4. The students are able to choose adjective correctly based on the picture 
5. The students are able to choose the definition of the word given

\section{Validity and Reliability}

The indicators of vocabulary learning result were developed to be instrument. The instrument was objective test with 50 items. Those items were analyzed its validity using Pearson Product Moment Correlation Coefficient, reliability using Alpha Cronbach formula, difficulty index and discrimination power to obtain good instrument using Microsoft Excel 2010. After the items have been analyzed, the good items that valid, reliable, satisfactory and medium were chosen to obtain good data. The question items were left 33 numbers. But it was only used 30 good question items to simplify the data analysis.

\section{Procedure}

Procedures of the research are:

1. Planning. Planning phase of this research is preparing and arranging the research design to get the research data. Before conducting the research, the writer formulates the hypothesis based on some related theories and design teaching plan using word list on the word wall strategy in teaching vocabulary learning result.

2. Collecting Data. The data were collected by giving posttest to the students in experiment class and control class.

3. Data Analysis. The data collected from the sample classes were analyzed by using ANOVA after the pre-requisite analyses of normality and homogeneity have been fulfilled. 
4. Reporting. The research finding is reported and written based on the formal frame of writing.

\section{Result}

The research data were analyzed descriptively and inferentially. The descriptive statistic can be seen on the following table.

Table 1

The Frequencies tables of score on experiment and control class

\begin{tabular}{|l|c|c|}
\hline \multicolumn{1}{|c|}{ Statistics } & $\begin{array}{c}\text { Experiment } \\
\text { Class }\end{array}$ & $\begin{array}{c}\text { Control } \\
\text { Class }\end{array}$ \\
\hline N $\quad$ Valid & 35 & 35 \\
Mean & 1 & 1 \\
Std. Error of Mean & 79.40 & 76.77 \\
Median & 1.690 & .978 \\
Mode & 80.00 & 76.00 \\
Std. Deviation & $70^{\mathrm{a}}$ & 80 \\
Variance & 9.998 & 5.786 \\
Range & 99.953 & 33.476 \\
Minimum & 40 & 27 \\
Maximum & 63 & 60 \\
Sum & 100 & 90 \\
\hline
\end{tabular}

From the table above, Mean (Average Score) of Experiment class was 79.40 and control class was 76.77. in experiment class, the maximum score was 100 and the minimum score was 63 while in control class, the maximum score was only 90 and the minimum score was 60. It indicated that students who received word list on the word wall strategy were higher than students who did not receive word list on the word wall strategy. After the data were analyzed descriptively, the data were analyzed inferentially using One-Way ANOVA. The 
data was tested its normality (Kolmogorov Smirnov) and its homogeneity (Levene) as pre-requisite data analysis. The result of data analysis is presented as follows:

Table 2 : ANOVA

\begin{tabular}{|l|l|l|l|l|l|}
\hline & $\begin{array}{l}\text { Sum of } \\
\text { Squares }\end{array}$ & Df & $\begin{array}{l}\text { Mean } \\
\text { Square }\end{array}$ & F & Sig. \\
\hline $\begin{array}{l}\text { Between } \\
\text { Groups }\end{array}$ & 3119.751 & 7 & 445.679 & 43.185 & $\mathbf{. 0 0 0}$ \\
$\begin{array}{l}\text { Within } \\
\text { Groups }\end{array}$ & 278.649 & 27 & 10.320 & & \\
Total & 3398.400 & 34 & & & \\
\hline
\end{tabular}

The calculation showed that significant value is 0.000 . The significant value $0.000<0.05$, so $\mathrm{H}_{\mathrm{a}}$ was accepted and $\mathrm{H}_{\mathrm{o}}$ was rejected. $\mathrm{F}_{\text {observed }}$ also can be used to find out whether or not there is an effect of variable $\mathrm{X}$ on $\mathrm{Y}$ through comparing with $\mathrm{F}_{\text {table. It }}$ can be concluded that there is significant effect of variable $\mathrm{X}$ (Word List on the word wall strategy) on variable $\mathrm{Y}$ (vocabulary learning result).

\section{Discussion}

The researcher found that there was the significant effect of word list on the word wall strategy on grade eight students' vocabulary learning result at SMPN 198 Jakarta, the significance (Sig.) value is lower that $(<) 0.05$ and $\mathrm{F}_{\text {observedis }}$ higher that $\left.(>) \mathrm{F}_{\text {table}}\right)$, and this result appropriate with the research 
conducted by GulsinCosgun (2016) and Sitompul (2013). The research also proved the theory by Cosgun (2016) using a wordlist on the word wall in the class is an effective vocabulary learning strategy to improve their repertoire of words, the findings might attract the interest of both foreign language teachers and students, and encourage them in the way of adopting and mentioned strategy in their studies. theory by Thornbury (2002) supported that by using Wordlist is one of the Strategies to acquire the vocabulary easily and wordlist can be applied in the classroom because it is cheap and widely used among the students, it also can be learned in a short time.

The result of the study is helped the students in grasping the meaning of word easily. Wordlist on the word wall is a strategy of teaching English that effectively increase students' vocabulary in learning English. By using word list on the word wall, the students feel enjoyable, fun, active, and creative. The learning situation will be more challenging, it can help the students to retain target words more quickly. This statement is also supported by Millington and Siegel (2010) states "the creation of vocabulary lists should be taken as an important duty that can have profound implications, assuming the students will invest time and effort attempting to acquire the vocabulary item in addition to being evaluated on vocabulary test and the will probably acquire more knowledge about the target words since they spend considerable time engaged with new vocabulary.

The benefit from this strategy is the students will learn English easily, especially in vocabulary learning result because from this strategy, the students will apply this strategy to find out the meaning and will understand what the 
definition of the word is. They will remember about the words because at the last step, they should review what they already learn. Finally, they will remember about the meaning of the words and they can answer the questions from the teacher easily. Moreover, not all of the students in experimental class got high score but also there are still the students from experimental class that got low score. This is also happen in the control class, where not all of the students got low score but also there are still the students that got high score. However, this score does not cause effect for the result of the research because it is individual case. In addition, the weakness of this strategy is the students always want to do wordlist on the word wall strategy for study and too relaxed in learning. The findings also showed that appropriate instruction of a strategy can enhance the students' vocabulary learning result. This technique will help the teacher and the students in learning process activity.

The result also displayed that the students who received wordlist on the word wall strategy and were trained to use the strategy after studying the vocabulary is better than the students who did not receive the strategy. The using of the strategy is to find out the important point and get the meaning of the word easily. Therefore, the students that used wordlist on the word wall strategy get good score on post - test.

Furthermore, the research findings of the classroom research were satisfied. Wordlist on the word wall as a strategy helped the students to learn and make them easy to understand the meaning of the words in learning English. Using wordlist on the word wall strategy is not only for more fun, but also more 
importantly, for the useful practice and review of language lessons, thus leading toward the goal of improving learners' communicative competence.

\section{Conclusion}

In this research, the researcher found that the use of Wordlist on the word wall strategy can help the students to increase their ability in learning vocabulary. Furthermore, the researcher only use one class as sample which represents the research population, the result of this research can prevail to the whole members of the population which has been taken as samples of this research.

According to the research finding, it can be seen that the students' vocabulary learning result obtained by the students who were taught by using word walls are higher than the vocabulary learning result gained by the students who were not taught by using word list on the word wall strategy.

The implication of conducting this research which is done by giving treatment with word list on the word wall in the grade eight students of SMPN 198 Jakarta. This teaching strategy can be one of the options for teaching strategy that can be used by the teachers' class of SMPN 198 Jakarta.

If the researcher do the same research in other school but the level of students is the same, beside that the students and the condition is also the same presumably the result is almost the same with this research finding. 


\section{REFERENCES}

Cosgun, Gulcin (2016). The Impact of Using Wordlist in the Language Classroom on Students' Vocabulary Acquisition, Ozyegin University.

Piribabadi, A \&Rahmany R (2014). The Effect of the Keyword Method and Word-List Method Instruction on ESP Vocabulary Learning, Islamic Azad University, Takestan Branch, Iran.

Janis, Karen, Wanda, Jaen \& Terri (2009). Interactive Word Walls: More than Just Reading the Writing on the Walls. Journal of Adolescent \& Adult Literacy 52(5).

Sitompul Elsa (2013). Teaching Vocabulary Using Flashcards and Wordlist. English Education Study Program of Indonesia University of Education.

Kerlinger Fred N. Foundation of Behavioral Research. 2 edition. U.S.A: Holt, Rinehart and Winston, Inc; 1983. p 29-40

Webster's II, New Riverside University Dictionary. (1984). Boston: The Riverside Publishing Company.

Murcia, M.C. (1978). Teaching English as a Second or Foreign Language. Rowley: Newburry House.

Thornburry, S. (2013). Teaching Vocabulary Using Short Text 1. ASIAN EFL Journal (online) Vol.2.1

Professional Testing Inc. (2006) Step 9. Conduct The Item Analysis. http://www.proftesting.com/test_topics/pdfs/steps_9.pdf.

UKessays (23 ${ }^{\text {rd }}$ March 2015) Vocabulary as an Important Component Of English Language Essay. https://www.ukessays.com/essays/english-language/vocabularyas-an-important-component-of-language-english-language-essay.php .

Harmon J Robert \& Morgan A. George (Search on January 2017) Research problems and variables. http://www1.appstate.edu/ kms/ classes/psy3100/Documents/Variables.pdf

B'P (Belajardanpembelajaran) (25 April 2013). PengertianPembelajaranMenurut Para Ahli. http://dedi26.blogspot.co.id/2013/04/pengertian-pembelajaran-menurutpara.html. 
Kompas .com, Retrieved on October 2016. Hasil UN Tahun 2016. http://search.kompas.com/cse?q=hasil+un+smp+2016

Leslie Owen Wilson (2017) Three Domains of Learning - Cognitive, Affective,Psychomotor. The Second Principle. http://these condprinciple.com/instructional-design/threedomainsoflearning/ 